\title{
Sharpening the epidemiological sword
}

\section{Eye (2006) 20, 1335. doi:10.1038/sj.eye.6702235}

Ocular trauma is often blinding, life changing and thought to be largely preventable. Nearly a quarter of a century ago, government intervention backed by sound epidemiological evidence dramatically changed the face of ocular injuries in the UK and many other developed countries with the introduction of the seat belt laws. ${ }^{1,2}$

The WHO Programme for the Prevention of Blindness estimates that there are still about 200000 open-globe injuries a year. ${ }^{3}$ Trauma is the most important cause of unilateral loss of vision in developing countries and up to $5 \%$ of all bilateral blindness is a direct result of trauma. ${ }^{4}$ The physical and psychological burden on individuals and society is tragic in the light of the fact that the majority are felt to be entirely preventable.

Rahman et al's work ${ }^{5}$ is an important study in helping to define why severe ocular injuries still occur. This sort of epidemiological data is crucial in helping local groups to address the underlying aetiologies.

Prior to the development of the Birmingham Eye Trauma Terminology (BETT), ${ }^{6}$ data from different studies was difficult to compare directly. Now with the foundation of the World Eye Injury Registry (WEIR), a strategy for collecting this data has been established and will be instrumental in combating preventable injuries.

WEIR is an international federation of country registries existing in cyberspace, which can be found at www.weironline.com. There is no fee to enter or retrieve data and standardisation of data entry will be undoubtedly pivotal in helping communities continue to drive down the incidence of open globe injuries. It is well recognised that there is great regional variation in the causes of severe
E Barnes

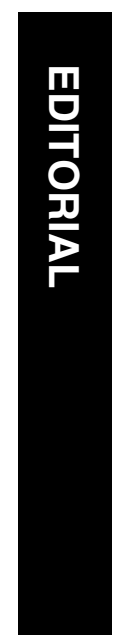

ocular trauma ${ }^{7,8}$ and almost certainly significant variation even at a local level.

Epidemiology is the first weapon in our medical arsenal; to make this sword truly sharp, every eye unit nationally and internationally should regularly contribute data to the World Eye Injury Registry. I urge you as ophthalmologists to join this international collaboration by designating a clinician within your unit who is responsible for data entry. With out this simple organisation within a unit, much useful data will be lost, progress will be slower and eyes will be lost.

\section{References}

1 Schrader W, Gramer E, Goldmann F, Marcus U. Penetrating and perforating eye injuries in 343 patients due to auto accidents before and after compulsory seat belt legislation resulting in fines (1966-1998). Klin Monatsbl Augenheilkd 2000; 217(1): 23-29.

2 Hall NF, Denning AM, Elkington AR, Cooper PJ. The eye and the seatbelt in Wessex. Br J Ophthalmol 1985; 69(5): 317-319.

3 Negrel AD, Thylefors B. The global impact of eye injuries. Ophthal Epidemiol 1998; 5(3): 143-167.

4 Thylefors B. Epidemiological patterns of ocular trauma. Austr NZ J Ophthalmol 1992; 20: 95-98.

5 Rahman I, Maino AD, Leatherbarrow B. Open globe injuries: factors predictive of poor outcome. Eye; advance online publication, September 23, 2005; doi:10.1038/sj.eye.6702099.

6 Kuhn F, Morris R, Whitherspoon CD, Heimann K, Jeffers JB, Treister $\mathrm{G}$ et al. A standardized classification of ocular trauma. Ophthalmology 1996; 103: 240-243.

7 Kuhn F, Mester V, Morris R, Dalma J. Serious eye injuries caused by bottles containing carbonated drinks. Br J Ophthalmol 2004; 88: 69-71.

8 Kuhn F, Mester V, Berta A, Morris R. Epidemiology of serious ocular trauma: The United States Eye Injury Registry (USEIR) and the Hungarian Eye Injury Registry (HEIR). Ophthalmology 1998; 95(5): 332-343.
Department of Ophthalmology, Royal Victoria Infirmary, Newcastle-upon-Tyne, UK

Correspondence: E Barnes, Department of Ophthalmology, Royal Victoria Infirmary, Newcastle-upon-Tyne NE1 4LP, UK

Tel: + 44191282 5451; Fax: +44 1912825446 . E-mail: eric.barnes@ nuth.nhs.uk 